\begin{abstract}
ARTICLES
Małgorzata Słod ow a-Hełpa (Poznań University of Economics

and Business, Poznań)

ORCID: 0000-0002-7312-3453

malgorzata.slodowa-helpa@ue.poznan.pl

\section{ECONOMIC POLICY FROM THE PERSPECTIVE OF CONTEMPORARY CHALLENGES IN ECONOMIC HISTORY - HOPES, CONCERNS AND DILEMMAS}

Abstract: The article, written on the basis of a critical review of the latest Polish and foreign-language literature, materials from websites and the author's experience gained from previous research, is treated as a voice in the discussion on new challenges and the need for historical research on economic policy in its various dimensions and contexts, and on the possibilities in this field. The premises which determined the title, nature and scope of the study were highlighted in the introduction. The following three parts attempt to answer the following questions in sub-headings: why is the turn to the problems of economic policy particularly desirable now? What premises justify and enable intensification of historical research on economic policy problems? How to study the past of economic policy to participate in managing the present and creating the future?
\end{abstract}

Keywords: social inequalities, state, COVID-19 pandemic, neoliberalism, heterodox economy, new concepts of economic policy

DOI: doi: 10.2478/sho-2020-0001

\title{
INTRODUCTION
}

It is difficult to find a more convincing justification of the need for research on various aspects of economic policy than its role in the process of stimulating development and overcoming the most difficult social and economic problems, both on a global, European, national, regional and even local scale. Although this issue has enjoyed unflagging interest for years and has been the subject of many in-depth analyzes, including these done by historians, economists, sociologists, political scientists, lawyers, 
and even psychologists, the demand for research in this field is still invaluable, both in terms of cognition and application.

Under these conditions, the title of this $38^{\text {th }}$ issue of Studia Historiae Oeconomicae $(\mathrm{SHO})$, together with a proposal of a wide range of problems that can be undertaken, including the conditions, manifestations and results of economic policy, its successes and failures, can be regarded as an exceptionally accurate response of the editorial office to contemporary challenges. They were the impetus to join this debate and inspired to look at selected aspects of economic policy research through the lens of new opportunities in this field, but also challenges that researchers of this policy must face in its various dimensions and scopes.

Placing fears and dilemmas in the title does not absolutely mean, therefore, doubts as to the need for research on historical aspects of economic policy, but dilemmas related to the manner of their implementation and a conviction of a clear need for improvement, especially in the conditions of deepening the "marriage" with economics and other disciplines of social sciences as well as intensifying the interdisciplinary debate on solving problems at various levels. Therefore, the starting point of the study, treated only as a voice in this important discussion, is an assumption regarding the unquestionable need to place historical research on economic policy on theoretical and methodological grounds and, on this basis, to arrange an appropriate research path defining methodological solutions.

Such an attitude of the researcher, postulated for a long time [Topolski J. 1983, 1996; Braudel F. 1999: 48-9] and only apparently obvious, is not simple, however, especially with the incredibly dynamic changes that have taken place in recent decades, both on the methodological and theoretical level, as well as in the sphere of economic practice and facing multidimensional challenges [Fischer L. et al. 2018]. It should suffice to indicate at least a few interrelated issues that show the scale of the problems and at the same time justify the scope and nature of this article.

- Firstly, the more and more clearly postulated and visible in the practice of social sciences transition from methodological and theoretical orthodoxy to pluralism and a specific complementarity of paradigms and synergy of the results of investigations in various disciplines, i.e. eclectic approaches, drawing from various schools of thought, reinforces the convicion that regardless from the scope and time horizon of research, economic historians should both take into account the achievements of other sciences and affirm the plu- 
ralism of approaches within their own discipline [Wallerstein I. 2007; Rodrik D. 2011, 2019; Horodecka A. 2013; Matera R. 2013; Csaba L. 2016; Gorynia M. 2016; Fiedor B. 2019: 41-7; Wilkin J. 2019: 57-63, Woźniak M. 2019: 43].

- Secondly, in conditions where, in the field of economic sciences, after several decades of domination of neoliberal economics on the theoretical and methodological level, more and more heterodox schools of thought are emerging as a counterbalance to it, there is a specific incorporation of this output needed in historical reserach, especially since such an approach is indicated by more and more researchers who emphasize that there is no one economy and that today no theory is better than another [Kołodko G.W. 2013, 2020a; Chang Ha-Joon 2015: 93; Keen S. 2017; Rodrik D. 2019; Mączyńska E. 2010, 2020].

- Third, the relegation of heterogeneity and alternative ways of thinking to the margins of academic economic education must also have limited economic historians' more pronounced openness to these achievements and weaken their ability to face multidimensional challenges.

- Fourthly, although in recent years historians have been opening up to a "different" economy, including institutional, but in relation to the demand it is still limited, especially since for several decades their turn to economics was perceived mainly through the lens of research in the field of new economic history, called cliometry, referring to the theoretical framework of neoliberal economics and verifying counterfactual models using econometric tools.

- Fifthly, historical research in the field of economic policy was influenced by the current way of practicing economics, including too rigorous approach and searching for universal truths that can be applied regardless of the context, creating imagined worlds in the form of models and metaphors leading to a narrowing of research visions and, in certain circumstances, to limiting progress in explaining reality [Rodrik D. 2019: 186; Wojtyna A. 2019: 70].

- Sixth, greater consideration of methodological and theoretical aspects would require an attempt to revise and reinterpret some of the previous research results, not only avoiding such reflection, but being an oversimplification of the reality much more complex than it might seem, as well as exposing some inconsistencies and myths on the basis of new experiences. 
In the context of the above-mentioned conditions, it is extremely difficult for economic historians to prepare an appropriate research "base" for various aspects of economic policy in the form of a solid theoretical and conceptual foundation, clear goals and hypotheses, precisely outlined assumptions exemplified in a multifaceted empirical layer. It is not enough to refer to a textbook of methodology or economics.

This belief of the author decided about the main goal of this article, which is to present contemporary challenges faced by researchers of historical problems of economic policy as well as new opportunities in this field and related fears and dilemmas. Therefore, it is not about presenting the results of empirical research, although, of course, with the existing research gaps, there is still a need for them, or about broader reflections in the field of historiography and historiosophy [Little D. 2017], which, in relation to economic policy research, would be undoubtedly also useful.

The article has the formula of a triptych, in which - against the background of premises determining the increasing importance and exceptional topicality of economic policy issues in its various dimensions - selected leading issues are outlined in the form of interrelated questions highlighted in the titles of the following subsections.

The subject of the first part, which is an extension of the aforementioned position regarding the need for research on the functioning and evolution of economic policy, is an attempt to answer the question: why is the turn to the problems of economic policy particularly desirable now?

The second part, entitled: What premises justify and enable intensifying of historical research on the problems of economic policy?, already takes the reader to the ground of economic history and presents related arguments confirming, on the one hand, the thesis about new demand and, on the other, about possibilities in this field.

In the next, third, part entitled: How to study the past of economic policy to participate in managing the present and creating the future?, selected postulates were signaled, the respect of which may strengthen the application advantages of the conducted research.

This article cannot aspire to a comprehensive approach to the issues outlined, not so much because of its vastness and the need for even more in-depth theoretical and application reflection, but due to the volumetric rigors that forced the text to be narrowed down and clearly hindered the wider presentation of the aforementioned aspects. Although the perceived insufficiency would certainly be reduced by publishing each of the three components in the form of an independent study, the adopted structure 
was largely determined by the conviction that some of the identified problems lie precisely at the interface between the components included here.

The basis for the preparation of the text was a critical review of the latest Polish and foreign-language literature on the subject and materials from websites, enriched with the author's experiences gained from previous research [Słodowa-Hełpa M. 2013b, 2014, 2015a, 2019]. One of the impulses to return to this issue, but from a different perspective, were the dynamic changes that we have experienced in recent decades, affecting not only the background and scenography of research, but also the demand that determines their directions and the work results of part of scientists.

The preparation of the article coincided with the events which also influenced its final shape. On the one hand, the COVID-19 pandemic and its spreading worldwide have become a source of a range of new challenges and threats, and forced us to seek solutions to difficult problems that the world has not faced on such a large and multidimensional scale. This situation, even more than the previous crises, exposed the errors and imperfections of the functioning of the current economic policy and became a magnifying glass revealing its weak points, forcing even a reevaluation of the concepts previously treated almost as dogmas.

On the other hand, in parallel and irrespective of the pandemic's expansion, many inspiring works appeared on the foreign and domestic publishing market, which immediately echoed in an interdisciplinary debate that also covered economic policy issues. Among them are Rutger Bregman's latest book with the meaningful title Humankind: A Hopeful History [Bregman R. 2020a], which is an excellent example of a revaluation influenced by the results of extensive historical research. Although this extensive and hopeful work was not created as a wipe of tears, there is quite a consensus that there was no better time to publish it than during the pandemic. The author, a philosopher and historian, focused his painstaking research on understanding human nature and referring to its critical image that has been functioning for centuries in the political debate. Its main message, drawn from extensive analyzes of known themes from antiquity to recent times, is that we do not necessarily have to look at humanity as Thomas Hobbes' disciples, since most of the society is decent, does good and can be trusted, and belief in goodness can be the foundation of lasting social change. Even if Bregman's position does not convince everyone, then - regardless of the debatable and polemical issues - the book is a perfect example of how placing the historical process in new contexts 
can influence the perception of the model of the economic man, which has been one of the main subjects of dispute for years [Horodecka A. 2011b, 2012: 11-39, 2014: 166-80, 2018; Dzionek-Kozłowska J. 2016: 102-21; 2018]. At the same time, it confirms that the image of the economic man, inseparably connected with economic policy, requires a holistic view and discovering the other half of homo oeconomicus.

In the main parts of the article, readers will find references to other recent works in which the center of attention was precisely economic policy [including: Atkinson A.B. 2015; Piketty i co dalej... 2018; Piketty T. 2015, 2018, 2020; Rodrik D. 2019, Skidelsky R. 2020a]. The positions of Polish authors will also be highlighted, especially prominent economists with extensive experience in implementation of economic policy at the government level [Kołodko G.W. 2013, 2014, 2017, 2020a; Hausner J. 2019a, b, 2020a].

The issues raised here will be continued in the next $39^{\text {th }}$ issue of $\mathrm{SHO}$, where, inter alia, the problems of the economic transformation policy, industrial policy and state actions for integrated development will be developed.

It will be the author's satisfaction if these "trailers" encourage people to read the main text, and the content of the article proves to be inspiring in the research work of economic historians to whom it is addressed and prompts them to discussion.

\section{WHY IS THE TURN TO THE PROBLEMS OF ECONOMIC POLICY PARTICULARLY DESIRABLE NOW?}

An economy without value is like a life without meaning ${ }^{1}$.

If something pays off, it doesn't mean it's worth it ${ }^{2}$.

The growing importance and exceptional topicality of economic policy issues in its many spheres and dimensions, from difficult-to-solve global and European challenges known as Gordian knots of the present day to various scales and nature of internal conditions, requires intensified research aimed at searching for effective ways of conducting this policy. This

\footnotetext{
${ }^{1}$ Kołodko G.W. [2013: 156].

2 Hausner J. [2019b].
} 
is because not only researchers of many disciplines, but also politicians, economic practitioners, and social activists, more and more often have to face challenges that go beyond previous patterns and require thinking and acting in a different way than before. Although the past two decades have been a period of sharp disputes over the role and optimal shape of this policy, there are more and more voices in the scientific discourse that economic policy issues should be given even more space and other ways of pursuing it should be sought. We are currently dealing with feedbacks expressed in the fact that reality has become a catalyst for research directions and the views resulting from them, which in turn affect changes in the management of this reality. In these interactions between science and the practice of economic life, historical research cannot be overestimated.

Among the phenomena and processes which in the past decades more and more clearly exposed the inconsistencies between theory and applied economics affecting the implemented economic policy, weakened their reputation and became an impulse to look for new goals, principles and instruments of this policy, the following deserve special emphasis:

- increasing income inequalities and widening scale of poverty and exclusion,

- post-communist transformation in the countries of Eastern Europe,

- the global financial and economic crisis of 2007-2012,

- increasing environmental threats and the need to link the economic system with the ecological one,

- globalization and the increasing complexity and variability of the environment,

- the COVID-19 pandemic, the scale, extent and nature of which may not even be comparable to previous crises.

Although various aspects of inequality, situated at the interface between economic efficiency and social justice, have a centuries-old tradition, much longer than the science of economics, they have been clearly ignored by economists for years [Malinowski G. 2016b: 6]. A pioneer and mentor of later researchers, including Thomas Piketty, was Anthony Atkinson, who dealt with inequalities since the early 1960s, long before they became appreciated and fashionable and at a time when they were at a relatively low historical level. Called, by Piketty, the godfather of the modern research scholarship on the distribution of income and wealth [Piketty T. 2017], he has repeatedly said that he does not postulate total equality, but a reduction in income inequality, which is a real problem in 
global economies [Atkinson A.B. 2017]. At the same time, he emphasized that while focusing on fighting poverty calms the consciences of the elite, it is an ineffective way to reduce inequalities and, apart from this much wider problem, cannot be solved. When assessing such practices critically, he compared them metaphorically to sticking a plaster on a cut leg [Woś R. 2017].

It was Atkinson, together with Simon Kuznets ${ }^{3}$, who made a clear contribution to the collection and to subjecting comprehensive data on national product, investment and employment to an extensive statistical and econometric analysis. He went even further, pointing to the strengths of historical analysis in collecting such sources, and his groundbreaking research was largely the inspiration for later work on historical trends in income and wealth inequality.

In recent decades, when inequality has risen rapidly and the concentration of income in the hands of the richest has reached record levels, the question of what needs to be done to make the distribution of goods more balanced, especially as the difficult problems of income inequality and growing poverty have increasingly affected growth and economic development, while the most economically effective solutions turned out to be unfair. In a short time, the problem of inequality ceased to be a peripheral and marginalized thread of economic reflection, and became one of the greatest challenges faced by leading economists and analyzes conducted by the most important international organizations and renowned research centers [Malinowski G. 2016b: 7]. In many debates and publications, the metaphor of the so-called cup of shame, illustrating the disproportions between the richest part of society, which has what is in the cup (80-90\%), and the other, many times more numerous group, having only what is dripping from it (10-20\%) [Mączyńska E. 2017: 200].

The weaknesses of the previous economic policy, but also of economic theory, were spectacularly highlighted by the already mentioned global economic crisis [Postuła M. 2019: 22-3]. It proved that the tools used so far made it impossible to predict or prevent it. Struggling with the effects of the economic slowdown and financial turmoil as well as building new solutions mitigating the consequences of crisis phenomena required increasing the role of governments and supranational organizations.

${ }^{3}$ Laureate of the Bank of Sweden Award, author of the book Economic Growth of Nations. Total Output and Production Structure [Kuznets S. 1976]. 
The severity of the crisis as well as the increasingly frightening results of the annual reports prepared for the needs of the World Economic Forum in Davos [Mączyńska E. 2017: 199, 2018a: 35] showing the scale of growing income and social inequalities certainly influenced the stunning success of the French economist's book Capital in the 21st Century [Piketty T. 2015], which further intensified the discussion around these issues ${ }^{4}$. It touched many circles and triggered extreme opinions - from delight to indignation, accusations of errors, author's ignorance and his anti-capitalist mentality [Murphy R.P. 2014; Reisman G. 2015]. Regardless of the polemical issues, it would be difficult to ignore this work in silence, if only because - as the author writes - it is based on lessons from historical experience and also presents abundant materials for further analysis.

The nature of the debate on the goals and instruments of economic policy was influenced by other works published in recent years, including:

- another excellent book by Atkinson, published in 2015, and in Polish translation in 2017, entitled Inequality: What can be done? which - as it later turned out - became the author's academic testament [Atkinson A.B. 2017]. He has included fifteen proposals of potential actions and instruments of economic policy addressed to the governments of OECD nation states and their citizens, aimed at reducing disproportions between social groups which are glaring and dangerous for democracy [Kanclerska A. 2017; Piketty T. 2017, 2018];

- extensive collective work: After Piketty: The Agenda for Economics and Inequality, containing not only the reactions of many recognized economists to Piketty's book, but, as the title announces, their view of the problems of modern economics [Piketty i co dalej... 2018];

- Piketty's most recent, powerful work Capital and Ideology [Piketty T. 2020, 1081 pages] with an empirical layer even wider than before, transporting readers much further beyond Europe and the West, to Asia and Africa, and covering the important problems - first of all, the global system of inequalities with all their varied causes and consequences - with which contemporary economic policy is confronted. It was based on the original thesis that inequality is neither

${ }^{4}$ Recognized as a sales hit by Harvard University Press, number one on the New York Times, Financial Times, McKinsey bestseller lists and for the 2014 Business Book of the Year and Amazon's Bestseller. 
a technological nor an economic phenomenon, but a political and ideological one.

The new wave of debate over economic policy issues is also reflected in the abundant publishing results of Polish researchers.

The monograph by Grzegorz Malinowski [2016b]: Nierówności i wzrost gospodarczy. Sojusznicy czy wrogowie [Inequalities and economic growth. Allies or enemies], situated in the mainstream of the economy, made an undoubted contribution to the research on inequalities in the distribution of income and the instruments of economic policy that limit them. Together with the original article on the perception of inequality and its disrupting factors, as well as with other works by the author [Malinowski G. 2014, 2016a], it contributes to a better understanding of relationships between income distribution and economic growth yet not explained satisfactorily [Woźniak M.G. 2017: 352].

The changing views on the need for a new paradigm of economic policy as well as a new economy of the future is reflected in the work of outstanding Polish economists and, at the same time, experienced politicians.

Grzegorz Kołodko, one of the architects of Polish economic reforms, whose work has a lot of echo and is recognized by leading economists in the world ${ }^{5}$, has for over a decade been pointing to the necessity of the economy of moderation in the form of the concept of new pragmatism, which is a response to contemporary challenges of globalization - a kind of interface between economic theory and practical economic policy for sustainable development. Already in the book Whither the World: The Political Economy of the Future, he stated that pragmatism is a fundamental, indispensable feature of rational management [Kołodko G.W. 2013]. In many of his other works, he consistently emphasizes that the new pragmatism, as a practical economic theory, as opposed to state capitalism, left-wing and right-wing populism, new nationalism and the utopia of collective capitalism, creates opportunities to meet epochal challenges [Kołodko G.W. 2020a: 15]. He argues that pragmatism deriving from a system of values is

\footnotetext{
${ }^{5}$ For example, Francis Fukuyama recognizes prof. Kolodko as one of the most insightful observers of the world economy, combining rich practical experience with academic achievements. Prof. Vito Tanzi claims that: while many of his contemporaries focus on trees, and some even on the bark of trees, Professor Kolodko is interested in all forests in the world. And not only today, but also past and future. Prof. Robert Mundell, Laureate of the Bank of Sweden Award, emphasizes that: he has extensive experience and his own views on phenomena, processes and trends in the global economy [Kołodko G.W. 2020a].
} 
needed, that foster participatory globalization, social cohesion, multiculturalism and sustainable development. He clearly explains what and why is happening in the economy, at its contacts with society and politics, the natural environment and security, culture and technology [Kołodko G.W. 2014, 2017, 2019, 2020a]. The achievements of Professor Kołodko in recent years have been an important starting point for many debates and conferences on a national and international scale, the aftermath of which are valuable collective works containing papers and voices in discussions by recognized researchers ${ }^{6}$.

In the opinion of Jerzy Hausner, also an experienced economist and politician, the basic weakness of neoclassical economics is the removal of the problem of value from it, reducing the economy to market valuation and resulting in the definition of the market as a self-regulating mechanism. He develops these issues in a monograph entitled: Społeczna czasoprzestrzeń działalności gospodarczej. W kierunku ekonomii wartości [Social space-time economic activity. Towards an economy of values] [Hausner J. 2019a] and in numerous articles [Hausner J. 2019b, 2020a] and media appearances, e.g. an interview eloquently titled, recognized as the motto of this part of the article [Hausner J. 2019c]. He emphasizes that the economy must not only analyze efficiency and growth, it must primarily focus on quality of life and development. It is necessary to rebuild and revive the tradition of being rooted in moral philosophy. In this context, Hausner points out that the adopted cognitive perspectives and related concepts should favor the empowerment of individuals and communities, while currently they support their objectification. Economics is to be primarily an "economy of values" [Hausner J. 2019b: 177].

Both of the above positions correspond to ordoliberal ideas and the concept of a social market economy, which is a counterbalance to neoliberalism and the quintessence of the economic model which the world treats with increasing favor. Many economists and politicians treat it as

${ }^{6}$ In 2016, a book was published entitled Ekonomia przyszłości. Wokót nowego pragmatyzmu Grzegorza W. Kotodko [Economics of the future. Around the new pragmatism of Grzegorz W. Kolodko], in the introduction of which editor Maciej Bałtowski [2015] included a valuable attempt to recreate and organize the scattered meanings of new pragmatism [Ekonomia przyszłości... 2016], and the co-authors took up its various aspects. In turn, in 2019, the work Ekonomia i polityka. Wokót teorii Grzegorza W. Kołodko [Economics and Politics. Around the theory of Grzegorz W. Kołodko] was published under the editorship of Elżbieta Mączyńska, including the voices of many recognized economists, such as: J. Wilkin, M. Gorynia, M. Postuła, M.G. Woźniak [Ekonomia i polityka... 2019]. 
a kind of "third way" in which economic and social interests are reconciled. In the milieu of Polish economists, his greatest promoter is Elżbieta Mączyńska, President of the Polish Economic Society, who in many of her works [Mączyńska E. 2018b, 2020c; Mączyńska E., Pysz P. 2020] justifies purposefulness of both, dispelling conceptual confusion resulting from injustified equation of ordoliberalism and neoliberalism, and even treating them as synonymous, as well as explanation of the essence of this concept, which after all is recognized as the basis of the economic system both in the Constitution of the Republic of Poland ${ }^{7}$ and in the treaty regulations of the European Union.

Against this background, surprising must be the extremely sharp reaction to the reports about growing inequalities and their consequences for the economic policy of Leszek Balcerowicz, an economist who has been deputy prime minister and minister of finance since 1989, responsible for carrying out a program of reforms related to the political transformation in Poland (the so-called Balcerowicz plan), who called the results of the subsequent Davos report ${ }^{8}$ "populist, emotional nonsense" and the opinions about them "vulgar analysis" [Żakowski J. 2017]. This position had to be criticized, even by some economists, like him, associated with the neoliberal tradition. After all, the growing stratification, not only among scientists, but also among many economic politicians, is considered one of the greatest contemporary problems. Christine Lagarde, president of the European Central Bank and previously the director of the International Monetary Fund, aptly described it a delayed bomb.

In recent months, when most countries were suddenly shaken by the Covid-19 pandemic, accompanied by a state of permanent sense of threat, it turned out that on the one hand, on a global scale, we are dealing with an experience completely different from the previous ones, but on the other hand confirming the thesis about a huge turbulence and unpredictability of the modern world

The coronavirus has launched a great "global interdisciplinary debate" involving almost all academia, political, professional and social back-

${ }^{7}$ Its article 20 of Constitution of the Republic of Poland of 2 April 1997 states that a social market economy based on economic freedom, private property and solidarity, dialogue and cooperation between social partners is the basis of the economic system of the Republic of Poland [Dz.U nr 78 poz. 483].

8 One can meet opinions, although few, that Oxfam, which is preparing these reports, is not an impartial scientific institution and theses about growing inequalities are a marketing ploy that helps it raise funds for its activity [Gadowski W. 2020]. 
grounds. Obviously, the positions are varied and it would be difficult to even hint at their various aspects ${ }^{9}$. The dilemmas of economists are reflected in meaningful titles most often presented in the form of questions, for example: Jak będzie wygladat świat po pandemii? [What will the world look like after the pandemic?] [Kołodko G.W. 2020b], "Nowa Normalność" czy kryzysogenny nieład? ["New Normality" or a crisis-producing disorder?] [Mączyńska E. 2020d], Jak poradzić sobie z koronawirusem?, Co nas czeka po Covid-19? Czy Covid-19 zmieni gospodarkę i nasze o niej myślenie? [How to deal with the coronavirus? What awaits us after Covid-19? Will Covid-19 change the economy and our way of thinking about it?] [Gorynia M. 2020a, b, c].

It is hard to disagree with Grzegorz Kołodko that it is currently impossible to satisfactorily answer the question of what the world will look like after the pandemic and it is easiest not to ask such questions [Kołodko G.W. 2020b]. However, only the selected positions presented below prove that Covid-19 also changes the way people think about the path traveled, and this is a challenge and inspiration for researchers of the past of economic policy, who may have their share in the "production of the anti-crisis vaccine".

The position of the economist Elżbieta Mączyńska, who often refers in her works to historical conditions, can be a confirmation. It claims that:

Without a detailed diagnosis of the underlying crises and weak crisis resistance, the development of such a "vaccine" becomes problematic. The thesis about the necessity to develop a new model of socio-economic order and a new rethinking of the statemarket-society relations is becoming more and more visible. Economic history shows, however, that the lessons of the crisis can be learned properly, but also that they can be understood or misused ${ }^{10}$ [Mączyńska E. 2020b].

A pandemic is a kind of magnifying glass that shows the lack of resistance of increasingly globalized and interconnected economies to crisis phenomena. [...] Although now, in the year of the COVID-19 pandemic, the emerging dysfunctions of the modern world are attributed to this pandemic, the symptoms and signals of crisis threats have been known for years or even decades. They were already spectacularly highlighted by the financial crisis of 2008. Unfortunately, as the economic history shows, the memory of a crisis is usually short, and the lessons that crises give are not infre-

${ }^{9}$ These issues, also raised in dozens of debates and statements by foreign researchers, shed new light on the problems of economic policy [Acemoglu D. 2020; Bowles S., Carlin W. 2020; Rodrik D. 2020].

10 The author doubts whether the term "new normality" is valid as it suggests the existence of normality before the COVID-19 pandemic. Meanwhile, however, it is difficult to conclude that the pre-pandemic situation in the global economy was marked by normality. 
quently taught too carefully, the basis of crashes is ignored, and the treatment is often focused not on eliminating the causes of diseases, but relieving their symptoms [Mączyńska E. 2020c].

Rutger Bregman [2000b], who in many interviews refers to historical experiences and to the conclusions of his flagship work, believes that the pandemic may be a turning point that humanity needs.

According to Grzegorz Kołodko [2020a: 45]:

Fundamental questions that would have to be asked anyway, and which the crisis caused by the coronavirus pandemic only highlights, concern the shaping of the state and market relations, democracy and centralism, multilateralism and unilateralism, the role of international organizations, both governmental and non-governmental, and above all the dilemma: controlled world politics and inclusive globalization or the spontaneous clash of civilizations.

In the article Koronawirus niejeden ma wymiar [Coronavirus has more than one dimension], M. Gorynia [2020d] emphasizes that:

only the simultaneous interdisciplinary development of this peculiar puzzle can lead to its understanding, and then to forecasting, searching and defining remedial measures.

Although the doubts expressed in the question may arise: is it the right time to turn to the past at this particular time, when the background and scenography in the theater of history changed almost instantly, right now, when society is waiting for so many pressing problems to be resolved? the positions already mentioned constitute a partial answer to them. The subsequent parts of the article will also be an attempt to show that - regardless of understandable cognitive considerations - this turn is justified and practically even more necessary than before. 


\section{WHAT PREMISES JUSTIFY AND ENABLE INTENSIFYING OF HISTORICAL RESEARCH ON THE PROBLEMS OF ECONOMIC POLICY?}

Europe must grow old, that is, philosophically digest the heritage of history in order to find a new language to describe the multi-story transformations of the world. Only when it has a language it can create recipes for complex civilization problems ${ }^{11}$.

Following the voice of Marc Bloch: even the most complex contemporaneity does not have the privilege of self-sufficiency. It would also be difficult to argue with his other statement that ignorance of the past inevitably results in a misunderstanding of the present [Bloch M. 1960: 16, 18].

The present situation directs thoughts almost naturally to the path traveled, to the experiences and warnings that flow from it, and to the possibilities of using them in managing the present. Despite the fact that the analysis of relations occurring in the past gives only some suggestions as to the present and future dependencies, it allows for the assessment of phenomena not only in a static, synchronous, but also diachronic perspective, so it allows us to think dynamically.

The renaissance of the historical perspective, which is in a way a reaction to the excessively narrow empiricism or ahistorical theorizing that previously occurred in economic sciences for several decades, makes it necessary, but also possible to make up for the previous limitations. An increasing group of researchers representing various currents of economic sciences notices the negative effects of the ahistorical approach so far and points to the need to historicize economics, i.e. to enrich it with a historical perspective enabling genetic thinking, and in special cases cause-effect and allowing for the determination of regularities. After all, it is economic history that provides many arguments from various epochs and geographical areas to show how costly errors can be and are in shaping the socio-economic system and implementing economic policy. It also proves that the change of the civilization pattern following a technological breakthrough has always been accompanied by crisis phenomena and the destruction of the old system in favor of the new one. It is therefore the right time and the need to obtain from the historical "laboratory" a "preparation" enabling the control and modification of some concepts built in ahistorical perspective, as well as a better understanding of human behavior.

${ }^{11}$ Peter Sloterdijk, Quote after [Lewicki 2019]. 
The greater than before demand for reaching to the historical legacy is justified not only by the increasingly popular concept of path dependence, but also by widely used in many areas of economic research the concept of so-called social embeddedness of the economy deriving from the so-called new economic sociology, mainly from the works of Mark Granovetter [Słodowa-Hełpa M. 2019].

For researchers of various aspects of economic policy, concepts of regional development based on territorial cohesion as well as smart specializations rooted in tradition, not only economic, but also cultural, also open a new field of application. In some regions, heritage is perceived as a catalyst for development processes, an important potential, but unfortunately often "dormant" or temporarily lost. In such conditions, the demand for the voice of economic historians joining this trend of changes is even more justified [Słodowa-Hełpa M. 2015a; 2019].

It sometimes happens that when various intellectual and emotional attitudes as well as concepts aimed at solving it are clarified towards a problem considered to be new, it turns out that the problem is not new at all. According to Witold Kula [1983: 183-4], although it is sometimes explained in a methodologically "naive" form, by showing that "something" has already happened in the past, this approach is also useful. It gives the issue under consideration a historical context, enables it to be more properly situated in the system of dependencies, and often also to follow previous experiences, and above all, an orientation in what is really new [Chang H.-J. 2015: 44-5].

Since, in the conditions of extremely dynamic changes, institutional solutions, including regulatory ones, but also theoretical concepts used in socio-economic policy, more and more often turn out to be inconsistent with the requirements of this new type of economy, the scope for new directions of historical research in this field is becoming even more visible. For if we look at the trends visible in the last few decades in the field of economics and reach for the "genealogy" of new, emerging trends, it is clearly visible that the impulses to revise some views as well as to change within economics came precisely from the historical "laboratory". Contemporary economists, pointing to deficiencies within the discipline, more and more often refer to historical experiences [Mączyńska E. 2010: 70; 2018b: 34-5].

The impulse to intensify historical research were also new possibilities of obtaining sources, enriching scattered and incomplete data, as well as much wider possibilities of their processing. For example, Atkinson and 
Piketty have successfully engaged in the organization of the World Wealth and Income Database, which cannot be overestimated from an inequality research perspective. Both of them emphasized in their works the far more favorable situation for contemporary researchers. For although the issue of income distribution and long-term trends was already at the center of interest of researchers of nineteenth-century political economy, especially Thomas Malthus, David Ricardo and Karl Marx, they could only draw on limited data and were therefore often forced to limit themselves to purely theoretical speculation.

For comparison, Thomas Piketty, using materials constituting the culmination of 15 years of research by a team of economists, presented historical analyzes of the evolution of income and property inequalities in as many as fifty countries. Starting with the United Kingdom and France in the 18th century, i.e. at the beginning of the industrial revolution, through analyzes of Germany and the United States, up to contemporary worldwide approaches, he showed the several-century-long metamorphosis of capital and distribution of income from labor, and on this basis he formulated political conclusions and normative as well as postulates concerning contemporary economic policy. In his latest work, Capital and Ideology, Piketty made use of an even broader substantive, temporal and spatial scope of his analyzes than before. As he concluded, his contribution to the research is expressed in placing the problems of inequality in a broad historical perspective and in a decentralized way of looking at the history of inequality [Piketty T. 2020].

He is not alone in such proceedings. There are many more examples of extensive historical analyzes aimed at searching for regularities and formulating postulates concerning contemporary economic policy. Due to the framework of this study, only selected can be signaled here.

Douglass North, who emphasized that the aim of his research is not only a new look at the past, but the inclusion in economic theory of an analytical perspective that allows understanding of economic change, found neoclassical static allocative efficiency incomplete and often leading to erroneous practical conclusions. He verified his hypotheses on the basis of extremely in-depth historical analyzes covering not only the development of the American economy, but also the European one. This is how he showed long-term processes and "paths of dependence" and the impact on the path of development of transforming institutions, ensuring either the development or permanent stagnation of countries and regions [North D.C. 1981, 1990, 2014]. Stressing that the economic system is a sys- 
tem of interrelated institutions, he noticed their "rooting" in the historical and cultural background and considered ideas, attitudes, behavior patterns and the sources of their formation as important factors influencing the success or failure in creating the welfare of nations [North D.C. 1990: 17; Słodowa-Hełpa M. 2013b: 60-2, 2015b: 74-5].

The impressive resources of historical sources were used by Daron Acemoglu and James Robinson, who also contributed to the new institutional economy as well as to solving the great problems of today. In the flagship work entitled Why nations fail [Acemoglu D., Robinson J. 2014] reached for materials from various periods and regions of the world, from the Roman Empire, through Mayan city-states, medieval Venice, England, continental Europe, the United States, the Soviet Union, Latin America and Africa. Their concept of extractive and inclusive institutions, previously presented together with Simon Johnson [Acemoglu D. et al. 2005], was an inspiration and was also used in the works of Polish economists and economic historians [e.g. Koryś P. 2018; Piątkowski M. 2018].

Oded Galor, the most significant achievement of whom is the Unified Growth Theory, the basis for the analysis of economic factors governing the evolution of individuals and societies throughout human history [Galor O. 2011], is known as on the one hand an economic theorist, and on the other as a researcher who significantly goes beyond its framework, boldly breaking the stereotypes and traps of proper thinking of some economists and economic historians [Osińska M. 2019: 32]. His research clearly interacts not only with history, but also with such areas of knowledge as: biology, anthropology, and cultural studies, opening new paths for creating the methodology of interdisciplinary research. They are a successful attempt at responding to the lack of consistency in two overlapping areas: longterm observation of empirical facts and their explanation by the theories of exo- and endogenous growth. As the author himself claims, his research aims to solve two of the most fundamental mysteries in the development process: the secret of growth and the secret of inequality in the wealth of nations [Galor O. 2019]. It does so through the lens of evolution, thus initiating controversial research into the interaction between the evolution of human biological and cultural characteristics and the process of economic development, and identifying which genetic characteristics of societies and individuals have led to such asymmetries. According to Professor Andreas Irmen, Oded Galor's Unified Growth Theory novel perspective on economic history challenges existing opinions and will inspire historical research in the future [Irmen A. 2019: 92]. 
However, the achievements of Oded Galor in the field of a unified theory of economic growth would not be possible without his previous research on the properties of the discrete dynamical system [Galor O. 2007]. In his model, he based the transition from stagnation to growth on the mathematical notion of bifurcation, applied to the nearly 1,000-year-old Malthusian stagnation, the industrial revolution and its aftermath, and the emergence of a modern dimension of human capital-based growth. It focuses on identifying the fundamental factors for exiting the trap of Malthusianism with primitive technologies, low living standards and labor productivity, the transition to the era of rapid growth with accompanying demographic changes, and then to the period of sustainable growth. In this way, he combined the mechanisms keeping the world economy in a stagnant trap with the innovative modeling of technology flywheels, which brought about a radical improvement in living standards, but significantly increased inequalities at the scale of countries and regions.

It is worth emphasizing that Oded Galor began his academic career as a theorist who determinedly analyzed the properties of new concepts and general equilibrium models. He then went on to develop a novel theoretical framework to better understand real-world problems. His path from theory to empirical analysis showed his versatility and resourcefulness, thanks to which he was able to radically change the methods he used and satisfy his intellectual needs. For these reasons, however, the Unified Growth Theory, perceived as an innovative concept belonging to the theory of socio-economic development, goes beyond the well-established framework of mainstream economics. It is based on more extensive methodological foundations, which makes it effective in explaining and interpreting the results of research on the course of the historical process of change.

The example of Oded Galor's path shows how efficiently moving in the sphere of economics, mathematics, statistics, econometrics, demography and even biology can significantly increase the possibilities of empirical verification of assumptions and thus the precision of considerations. Even if one were to argue with some of its assumptions and results, one should appreciate the ingenuity and freedom with which he moves through the series of statistical data. No wonder then that Robert Solow defined the Unified Growth Theory as a breathtakingly ambitious project, and Daron Acemoglu, recommending Galor's work, found it extremely inspiring, motivating and challenging for economists [Malaga K. 2019: 42-3].

We also have an increasing number of good practices in the field of original enrichment of source resources. Inspirational solutions in this 
field are contained in the works of Thomas Piketty. He confronts the results of surveys, often lowering the actual property inequalities, with documents from tax offices, from inheritance archives, with transaction data, or even with leaks from tax havens allowing to estimate the scale of tax avoidance. It presents the evolution of property inheritance, and analyzes the possible evolution of the global division of property at the beginning of the $21^{\text {st }}$ century. He also places great emphasis on comparative research on the dynamics of inequality in the world (e.g. France is opposed by the USA). He enriches all these analyzes with tables and graphs. That is why he is called an inequality cartographer.

There are also more and more successful attempts to use new, previously unknown statistical methods and models that clearly enrich analytical possibilities and fill the identified research gaps or revise previous views in the Polish home area. A good example is the study of changes in urbanization and GDP per capita in Poland in the years 1870-1910. Due to the annexation of these areas by three partitioners, it proved impossible to obtain comparable data sets for the entire territory. On the other hand, the marked differentiation of both the economic policy and the level and rate of GDP growth meant that the estimates included in the international database of A. Maddison and the estimates of other authors raised serious reservations. Therefore, for the needs of the new estimate, an econometric model was built and historical data was used, allowing for a significant increase in the credibility of the results obtained, then compared with the analogous indicators of the region's countries and highly developed economies of Western Europe [Bukowski M. et al., 2018: 13150; 2019]. There are also examples of conducting in-depth cliometric analyzes to assess the feedbacks (two-way connections) between the development of railways in Germany and economic growth in relation to long series (1872-1913) as well as one- and two-equation models taking into account the time variable $(\mathrm{t})$, conclusions from the Frisch-Waugh-Stone theorem [Myszczyszyn J. 2019]. 


\section{HOW TO STUDY THE PAST OF ECONOMIC POLICY TO PARTICIPATE IN MANAGING THE PRESENT AND CREATING THE FUTURE?}

Working with your head in the past, heart in the present and hope for the future ${ }^{12}$.

Although there is no single recipe, on the basis of the analysis carried out, it is worth reaching out to the opinions of authorities and quoting at least a few guidelines and postulates addressed along with the above motto to economic policy researchers, in the hope that respecting them will strengthen the application dimension of the research and will constitute at least a partial answer to the question formulated in the title.

It has already been emphasized many times that what we extract from past economic phenomena and processes for the present and the future depends primarily on the goals and methods of research, on the extent to which the narrative is subordinated to tracking regularities, discovering the principles of human action, methods and tools for effective stimulation of development [Mises L. 2011; Słodowa-Hełpa M. 2013b, 2019; Topolski J. 1998]. According to Popper's metaphor, the main condition for the implementation of the popular maxim 'historical experience teaches' is to set the spotlight of research questions so that they illuminate those fragments of the past that help to understand phenomena and processes important for the present [Popper K.R. 2002]. At the same time, it is necessary to skillfully distinguish what is only temporary from what lasts in the long run [Woźniak M.G 2019b: 6-7]. This is because only research into the past may become a source of warning signals for entities that formulate goals and directions of economic policy and implement them.

There are consistent opinions that due to the complex and distinctly differentiated mechanisms of economic policy implementation, revealing regularities in this field requires looking at the studied phenomena and processes from the perspective of long duration (long wave). It is postulated in particular by the authors who are influenced by the academic tradition of the French Annales School, especially F. Braudel [Wallerstein I. 2004, 2007; Acemoglu D. et al. 2005]. The previously mentioned Atkinson also consistently advised it.

12 Ajl M. [2019]. 
Increasingly, the importance of various aspects of comparative research and construction of descriptive models, the use of which requires comparability of data, is emphasized. Atkinson, known for his creative comparative studies requiring the use of empirical methods, repeatedly stressed that the precondition for reliable conclusions is the comparability of data [Atkinson A. 2017].

The appropriate conceptual framework is not without significance, as emphasized by D. North, combining the experiences of two disciplines economics and economic history. He emphasized the importance of skilful application of such a framework in the process of interpreting the economic past, especially in conditions when the analytical instruments used by economic historians turn out to be useless, e.g. for explaining the institutional structure underlying the economic system that affects its functioning and changes [North D.C. 1981, 1990].

The importance of terminological rigor is also indicated by Grzegorz Kołodko, who emphasizes that many disputes in the scientific debate stem from the fact that interlocutors presenting their views do not mean the same thing. Some use different names to describe the same reality, others use the same name for different realities. So it happens that after explaining the terms used, the subject of the substantive dispute or the reason of the political conflict disappears [Kołodko G.W. 2020a: 186].

The most effective, but also the most difficult way to make progress on the practical issues of public policy and social justice is to embed historical empirical analysis in a theoretical framework and combine the theoretical layer with a thorough systematic view of real phenomena and processes [Atkinson A.B. 2017; Piketty T. 2018, Galor O. 2011, 2019]. It is not possible to apply a specific economic theory without reflection. In practice, it is necessary to adapt it to the realities, which means that within the same discipline, given phenomena or processes can be analyzed from the perspective of "competing" epistemological positions.

Referring to the opinion of Dani Rodrik, who highlighted such a position in the title of his work One Economics, Many Recipes, and also developed in his book Economics Rules. The Rights and Wrongs of the Dismal Science, different circumstances require different models and it would be harmful to look for universal truths, because in different periods, countries or in particular markets social life is too varied to always be presented in the same way. In his opinion, "tailored" solutions are necessary, taking into account a wide context: historical, political, institutional, social and cultural [Rodrik D. 2011, 2019]. Jacek Kochanowicz [2015] empha- 
sized the importance of context in Polish historiography, emphasizing the contextual nature of history.

In the opinion of Robert Skidelsky, presented in his latest work What's Wrong with Economics?, the lack of realism in "model production" is at best a caricature, and at worst a parody of human behavior [Skidelsky R. 2020].

In the decades to come, the most promising and challenging research in the field of economic growth and development is likely to be the various forms of analysis of the interaction between human evolution and the development process. The exploration of this vast and largely unexplored area has the potential to revolutionize the understanding of the formation of human traits and their impact on behavior in general and the development process in particular. This can improve understanding of the origins of human behavior and global inequalities, and support the design of appropriate policies to promote economic development and reduce income disparities [Galor O. 2019].

\section{CONCLUSIONS}

Understanding the contribution of deeply entrenched factors behind the wealth disparity of nations can help countries design policies to mitigate the adverse impact of these historical forces and foster economic development across the planet - making the world a better place, with equal opportunities for all $^{13}$.

The views of Oded Galor cited earlier, and in particular the above motto derived from his latest article, in fact largely relieves the author, not only from answering the fundamental question: why the turn to the past is now justified and practically more necessary than before ${ }^{14}$.

As befits the formula of the conclusions, one should respond to the declarations contained in the introduction and answer the questions formulated in the text. Under the convention of this article, when the titles of the three main parts were formulated in the form of questions, it was

13 Galor O. [2020: 17].

14 On October 15, 2019, during the inauguration of the academic year at the Poznan University of Economics and Business, Prof. Oded Galor received his honorary doctorate of PUEB and delivered two lectures: inaugural and open on: The Journey of Humanity: Roots of Inequality in the Wealth of Nations. This lecture (Lecture given by Oded Galor during the ceremony in which he was awarded Doctor Honoris Causa from Poznań University of Economics and Business [Galor O. 2020: 7-18]. 
there that appropriate attempts were made to answer. Therefore, in order to avoid repetition, the leading question at this point is one of the important challenges for economic historians, namely: how, in the conditions of an apparent crisis, they can help to rethink the economy, in particular how they can contribute to the improvement of current and future politics economic?.

Although, of course, an unambiguous answer is impossible or extremely difficult, on the basis of a critical analysis of the abundant literature containing the positions of many researchers as well as the author's experience, one can nevertheless get some suggestions addressed to those who draft a revision scenario and enrich the economy in terms of goals and instruments of economic policy .

One of the basic conditions for their effectiveness in this field is undoubtedly the awareness of both the limitations arising from the orthodox paradigm of the mainstream economics and the possibilities of using the ideas and postulates of the more and more heterodox concepts that constitute a kind of its counterweight.

However, we are currently dealing with a specific paradox, expressed in the fact that, on the one hand, the current dominant in the process of academic education does not provide a coherent justification for the role and scope of economic policy pursued by public entities [Grodzicki M.J. 2015: 137; Kołodko G.W. 2020a]. On the other hand, some heterodox concepts that allow a more realistic look at the evolution of economic policy, exposing not only the need for an interdisciplinary approach, but also taking into account the historical and socio-cultural context, are in the nascent phase, not yet fully defined. For these reasons, the exposure and clearer openness of economic historians to the achievements of heterodox trends cannot come easily to them. Already in the 90s of the last century, John Galbraith pointed out how difficult it is to switch to a different way of thinking, in conditions when the basis of economic education were and still are neoliberal principles.

Generally speaking, in the theory of economics, three main groups of factors influencing the course of the historical process of economic growth and development are commonly distinguished, namely: the size and structure of the resources of production factors, the institutional order and its changes, and the model and quality of the economic policy conducted. Comparative research on the strength and nature of the impact of individual groups of factors on the historical process of economic growth was the basis for the dynamic development of the theory of economic growth in 
the first half of the $20^{\text {th }}$ century, both within the classical, neoclassical and Keynesian traditions. At the turn of the $20^{\text {th }}$ and $21^{\text {st }}$ centuries, there was an increase in the interest of researchers in the influence of the shape of the institutional order and its changes on the course of the economic growth and development process. It was caused, among others, by the phenomenon of divergence observed since the nineteenth century, both between the studied countries and within individual national economies. Over the past two decades, an influential body of research has emerged focused on uncovering the evolutionary roots of comparative economic development across regions and countries. More and more often and more clearly, the undoubted limitations of economic policy research resulting from the features of the neoliberal economy are also pointed out. In particular, the reservations refer to the following principles and features [Horodecka A. 2017, 2018; Mączyńska E. 2019, Mączyńska E., Pysz P. 2020]:

- simplified understanding of the rationality of economic entities and treating the economic system as relatively autonomous,

- narrow concept of a economic man,

- disbelief in the state's ability to sustainably improve the level and direction of economic activity and to change the distribution of wealth and income,

- isolating the meta-system from the diverse and changing historical background, as well as from the socio-cultural, natural and political environment,

- fetishizing economic growth and treating it as the leading goal and absolute priority of economic policy,

- treating GDP as a measure of socio-economic achievement.

Even a bitter accusation is directed at neoliberal economists that in an attempt to establish universal laws they consciously ignore the specificity of history and culture [Skidelsky R. 2020; Chang H.-J. 2015: 380-1]. According to E. Mączyńska [2019], in conditions when the entire concept of Adam Smith, the spiritual father of liberalism, was "cleared" of ethical issues, it is more legitimate to talk about doctrine than about liberal economy.

Objections about the shortcomings of the concept of the managing man (homo oeconomicus) are increasingly clearly articulated, affecting the quality of systems and models created on the basis of such a simplified image [Dzionek-Kozłowska J. 2016: 105-30, 2018; Horodecka A. 2016: 166-83; Woźniak M.G.]. Anna Horodecka, who has a dozen or so works on various aspects of the image of man in modern economics, formulated 
many inspiring questions and theses worth considering by economic historians [Horodecka A. 2018: 9-11], including whether such a narrow picture contributes to the loss of both the essence of man and the economy? Does the distance of people from one another and from the economic reality lead to harmful behavior and to disturb the basic goal, which should be satisfying the basic needs of the individual and society?

The aforementioned questions clearly correspond to the postulates of Michał Gabriel Woźniak [2019a: 31-50, 2020: 11-2] regarding the need to stimulate integrated development, in the light of which the task of economics and economic policy should be to respect the functions of goals of all spheres of human existence and the effects of synergy and entropy resulting primarily from alternative resource allocations. The conditions, dimensions and challenges of integrated development were also the subject of a monograph and several articles by the author [Słodowa-Hełpa M. 2013b, 2014: 20-42; 2015a]. There are therefore no isolated voices that a broader image of man, dependent not only on changes in the environment, but also on the image of the world, should be a key construct underlying both the theoretical framework for research and ways of learning about reality, as well as decisions related to the functioning and stimulation of the economy. This image of a human being fulfills a descriptive, positive and normative function and influences both scientific reflection on the economy and management, as well as the actual behavior of economic entities, resulting from their systemic grounding [Horodecka A. 2017: 2018: 9-11].

In this context, another question by Anna Horodecka [2018: 10] is justified, namely: What consequences could the adoption of other, more complex assumptions about man have for the development of the economy?

These and other shortcomings and gaps in mainstream economics may be compensated by the concepts of various schools of heterodox economics that justify a broader and deeper understanding of the historical evolution of economic policy. In addition, they are oriented to a much wider subject scope (ethical, social, ecological values), as well as taking into account the geographical, political, cultural and institutional context (e.g. new institutional and new geographic economics, economy: evolutionary, ecological, feminist, common good). [Chang H.-J. 2015: 97-145; Fischer L. et al. 2018; Horodecka A. 2017: 213-4, 217-8, 234; Słodowa-Hełpa 2015b, c].

With the growing dynamics of changes and the increasing complexity of the modern world, it is precisely the heterodox approach that may turn out to be an accelerator of development and an inspiration to create 
a new paradigm of economic policy [Fischer L. et al. 2018; Mączyńska E. 2010: 71].

It is worth bearing in mind the popular metaphor that the economy resembles a game of chess, so even a seemingly insignificant move changes the situation across the board. In the light of the selected good practices of historical analyzes presented in the text, carried out by economic historians, economists and researchers of other disciplines, and the impulses to revise some views as well as changes in economic policy they give rise to, it can be hoped that they will contribute to the right moves on the board even in these difficult crisis conditions.

Referring to the words often attributed to Winston Churchill that no crisis can be wasted, it is therefore also necessary to look at the present crisis in terms of the chance to win a game of chess by skilfully using the potential that paradoxically lies even in this pandemic reality.

The pandemic has exposed many weaknesses in the modern world and domestic economies. In order not to let the lessons learned from it go to waste, minor corrections are not enough. The so-called "New normality" requires profound reforms of the socio-economic system aimed at shaping crisis resilience [Mączyńska 2020c].

\section{REFERENCES}

\section{Literature}

Acemoglu D. (2020), Punkt przeciążenia, Dziennik Gazeta Prawna, 203(5356), 16-18 października, A16-A17.

Acemoglu D., Johnson S., Robinson J. (2005), Institutions as the Fundamental Cause of LongRun Growth [in:] Aghion P.A., Durlauf S.N. (eds.), Handbook of Economic Growth, Volume 1 Elsevier B.V., Amsterdam : North Holland, 385-472.

Acemoglu D., Robinson J. (2014), Dlaczego narody przegrywaja, Wydawnictwo Zysk i Spółka, Poznań.

Atkinson A.B. (2017), Nierówności. Co da się zrobić?, Wydawnictwo Krytyka Polityczna, Warszawa.

Bałtowski M. (2015), Ewolucja ekonomii a nowy pragmatyzm Grzegorza W. Kołodki, Ekonomista, 5, 575-593.

Bloch M. (1960), Pochwata historii, czyli o zawodzie historyka, Wydawnictwo Naukowe PWN, Warszawa.

Braudel F. (1999), Historia i trwanie, Wydawnictwo Czytelnik, Warszawa.

Bregman R. (2020a), Humankind: A Hopeful History, Bloomsbury Publishing.

Bukowski M., Koryś P., Leszczyńska C., Tymiński M., Wolf N. (2018), Wzrost gospodarczy ziem polskich w okresie pierwszej globalizacji (1870-1910), Ekonomista, 2, 127-155.

Bukowski M., Koryś P., Leszczyńska C., Tymiński M., Wolf N. (2019), Urbanization and GDP per capita: New data and results for the Polish lands, 1790-1910), Historical Methods: A Journal of Quantitative and Interdisciplinary History, 52(4), 213-227. 
Chang H.-J. (2015), Ekonomia. Instrukcja obstugi, Wydawnictwo Krytyki Politycznej, Warszawa.

Csaba L. (2016), Nieortodoksja, heterodoksja a ekonomia globalna, [in:] Bałtowski M. (ed.), Ekonomia przyszłości. Wokół nowego pragmatyzmu Grzegorza W. Kołodko, Wydawnictwo Naukowe PWN, Warszawa.

Dzionek-Kozłowska J. (2016), Homo oeconomicus w XXI wieku. Imperializm ekonomii a ekonomia behawioralna, [in:] Gorazda M., Hardt Ł., Kwarciński T. (eds.), Metaekonomia. Zagadnienia z filozofii ekonomii, Wydawnictwo Copernicus Center Press, Kraków, 105-130.

Dzionek-Kozłowska J. (2018), Model homo oeconomicus. Geneza, ewolucja, wptyw na rzeczywistość gospodarcza, Wydawnictwo Uniwersytetu Łódzkiego, Łódź.

Dz.U nr 78 poz. 483, Konstytucja Rzeczypospolitej Polskiej z dnia 2 kwietnia 1997 r.

Ekonomia i polityka. Wokót teorii Grzegorza W. Kołodko (2019), Mączyńska E. (ed.), Wydawnictwo Naukowe PWN, Warszawa.

Ekonomia przyszłości. Wokót nowego pragmatyzmu Grzegorza W. Kołodko, (2016), Bałtowski M. (ed.), Wydawnictwo Naukowe PWN, Warszawa.

Fiedor B. (2019), Podział na ortodoksję i heterodoksje w świetle potrzeby pluralizmu metodologicznego w ekonomii, perspektywa mikroekonomiczna, [in:] Gorynia M. (ed.), Ewolucja nauk ekonomicznych. Jedność a różnorodność, relacje do innych nauk, problemy klasyfikacyjne, PAN, Warszawa, 41-56.

Fischer L., Hasell J., Proctor J.C., Uwakwe D., Ward-Perkins Z., Watson C. (2018), Pomyśleć ekonomięod nowa. Przewodnikpogłównych nurtach ekonomii heterodoksyjnej, Wydawnictwo Ekonomiczne Hetorodox, Poznań.

Galor O. (2007), Discrete Dynamical Systems, Springer Verlag, Berlin-Heidelberg.

Galor O. (2011), Unified Growth Theory, Princeton University Press, Princeton \& Oxford.

Galor O. (2019), Gospodarka w świetle procesów ewolucyjnych, Z prof. Odedem Galorem, autorem jednolitej teorii wzrostu, rozmawia prof. Magdalena Osińska, Głos Uczelni, Czasopismo Uniwersytetu Mikołaja Kopernika w Toruniu, 11-12, 31-33.

Galor O. (2020), The journey of humanity: Roots of inequality in the wealth of nations, Economics and Business Review, 6 (20), 2, 7-18.

Gorynia M. (2016), Nauki ekonomiczne a postulat interdyscyplinarności, [in:] Czaja S., Graczyk A. (eds.), Ekonomia $i$ środowisko, Wydawnictwo Uniwersytetu Ekonomicznego we Wrocławiu, Wrocław, 122-130.

Gorynia M. (2020a), Jak poradzić sobie z koronawirusem, Rzeczpospolita, 04.02.2020, A 27.

Grodzicki M.J. (2015), Teoretyczne uzasadnienia dla prowadzenia polityki przemysłowej, Studia Ekonomiczne, 210, 130-138.

Hausner J. (2019a), Społeczna czasoprzestrzeń działalności gospodarczej. W kierunku ekonomii wartości, Wydawnictwo Nieoczywiste, Kraków.

Hausner J. (2019b), Ekonomia i społeczne imaginarium, Biuletyn PTE, 4(87), 21-28.

Hausner J. (2020), Ekonomia i społeczne imaginarium, Ekonomista, 2, 167-180.

Horodecka A. (2011a), Cele polityki gospodarczej w różnych podejściach metodologicznych ekonomii, Gospodarka Narodowa, 7-8, 113-138.

Horodecka A. (2011b), Koncepcja homo sustinens i jej rola w polityce gospodarczej wobec wyzwań globalnego kryzysu, [in:] Pająk K., Tomidajewicz J. (eds.), Polityka gospodarcza wobec globalnego kryzysu ekonomicznego, Wydawnictwo Adam Marszałek, Torun, 31-55.

Horodecka A. (2013), Ekonomia na rozdrożu: pomiędzy monizmem i pluralizmem metodologicznym, Prace i Materiały Instytutu Rozwoju Gospodarczego SGH, 92: Polityka gospodarcza w poszukiwaniu nowego paradygmatu, 271-303.

Horodecka A. (2014), "Homo oeconomicus” jako podstawa ekonomii - krytyka i alternatywy, Prace Naukowe Uniwersytetu Ekonomicznego we Wrocławiu, 347, 166-183. 
Horodecka A. (2017), Polityka gospodarcza w świetle przemian wspótczesnej myśli ekonomicznej, [in:] Stacewicz J. (ed.), Perspektywy polityki gospodarczej, Prace i Materiały Instytutu Rozwoju Gospodarczego SGH, 99, Oficyna Wydawnicza SGH, Warszawa, 211-239.

Horodecka A. (2018), Obraz człowieka we współczesnej ekonomii, Oficyna Wydawnicza SGH, Warszawa.

Horodecka Anna (2012), Funkcje obrazu człowieka w ekonomii, Prace i Materiały Instytutu Rozwoju Gospodarczego SGH, 88: Pomiędzy polityką stabilizacyjną i polityką rozwoju, 9-39.

Irmen A. (2019), A review concerning the proposal to confer the degree of doctor honoris causa from the Poznan University of Economics and Business on Oded Galor, [in:] Uroczystość nadania Odedowi Galorowi godności doktora honoris causa Uniwersytetu Ekonomicznego w Poznaniu, Wydawnictwo Uniwersytetu Ekonomicznego w Poznaniu, Poznań, 81-92.

Keen S. (2017), Ekonomia neoklasyczna: fatszywy paradygmat, Wydawnictwo Ekonomiczne Heterodox, Poznań.

Kochanowicz J. (2015), Ucieczka w historię. Ego lecture na Wydziale Historycznym Central European University 5 vi 2014 r., Roczniki Dziejów Społecznych i Gospodarczych, 75, 13-33.

Kołodko G.W. (2013), Dokąd zmierza świat. Ekonomia polityczna przyszłości, Prószyński i S-ka, Warszawa.

Kołodko G.W. (2014), Nowy Pragmatyzm, czyli ekonomia i polityka dla przyszłości, Ekonomista, 2, 161-192.

Kołodko G.W. (2017), Nowy pragmatyzm i jego znaczenie dla uczciwego gospodarowania, [in:] Mączyńska E., Sójka J. (eds.), Etyka i ekonomia. W stronę nowego paradygmatu, PTE, Warszawa.

Kołodko G.W. (2019), Ekonomia nowego pragmatyzmu: tożsamość, cele, metoda, Biuletyn PTE, $4(87), 28-39$.

Kołodko G.W. (2020a), Od ekonomicznej teorii do politycznej praktyki, Wydawnictwo Poltext, Warszawa.

Koryś P. (2018), Poland From Partitions to EU Accession. Modern Economic History, Palgrave/ Springer Nature, London.

Kula W. (1983), Historia, zacofanie, rozwój, Czytelnik, Warszawa.

Kuznets S. (1976), Wzrost gospodarczy narodów. Produkt i struktura produkcji, Państwowe Wydawnictwo Ekonomiczne, Warszawa.

Lewicki G. (2019), Dziedzictwa i zombie. Dlaczego należy wspierać krótkoterminowe prognozy analiza zjawisk długofalowych, Porównania, 1(24), 269-273.

Little D. (2010), New Contributions to the Philosophy of History, Springer Science, Dordrecht.

Malaga K. (2019), Oded Galor - doktorem honoris causa LAUDACJA, [in:] Uroczystość nadania Odedowi Galorowi godności doktora honoris causa Uniwersytetu Ekonomicznego w Poznaniu, Wydawnictwo Uniwersytetu Ekonomicznego w Poznaniu, Poznań, 34-52.

Malinowski G. (2014a), Nierówności dochodowe a wzrost gospodarczy w kontekście jednolitej teorii wzrostu gospodarczego, Kwartalnik Nauk o Przedsiębiorstwie, 3, 38-47.

Malinowski G. (2014b), Percepcja nierówności społecznych a rzeczywistość, Nierówności Społeczne a Wzrost Gospodarczy, 38(2), 118-135.

Malinowski G. (2016a), Ekonomia umiaru - przyszłość możliwa czy nieuchronna?, [in:] Pach J., Kowalska K., Szyja P. (eds.), Ekonomia Umiaru - realna perspektywa?, Wydawnictwo Naukowe PWN, Warszawa, 115 - 132.

Malinowski G. (2016b), Nierówności i wzrost gospodarczy. Sojusznicy czy wrogowie, Wydawnictwo Naukowe PWN, Warszawa. 
Matera R. (2013), Łaczenie ekonomii i polityki w badaniach interdyscyplinarnych. Wyzwania dla ekonomisty, politologa i historyka, [in:] Kalinowski M., Pieczewski A. (eds.), Polityczna kreacja ładu ekonomicznego. Teoria i praktyka, Wydawnictwo Uniwersytetu Łódzkiego, Łódź, 17-34.

Mączyńska E. (2010), Ekonomia w warunkach gospodarki nietrwałości, [in:] Mączyńska E., Wilkin J. (eds.), Ekonomia i ekonomiści w czasach przełomu, PTE, Warszawa, 59-70.

Mączyńska E. (2017), Asymetrie społeczno-gospodarcze w kontekście teorii ekonomii i etyki [in:] Mączyńska E., Sójka J. (eds.), Etyka i ekonomia. W stronę nowego paradygmatu, PTE, Warszawa, 195-215.

Mączyńska E. (2018a), Chaos w gospodarce globalnej, potrzeba instytucjonalno-ustrojowego ładu. Wybrane refleksje na tle studiów literatury przedmiotu, Biuletyn PTE, 2(81), 34-44.

Mączyńska E. (2018b), Ordoliberalizm i społeczna gospodarka rynkowa jako podstawa inkluzywnego systemu społeczno-gospodarczego, [in:] Mączyńska E., Pysz P. (eds.), Społeczna gospodarka rynkowa: Polska i integracja europejska, PTE, Warszawa.

Mączyńska E. (2020a), Antidotum na kruszący się świat, Dziennik Gazeta Prawna, 148(5301), 31.07.-02.07.2020, A12.

Mączyńska E. (2020b), "Nowa Normalność” wymaga głębokich reform systemu społeczno-gospodarczego, Rynek Opinii, Biuletyn Gospodarczy, 2, 17-18.

Mączyńska E. (2020c), Społeczna Gospodarka Rynkowa. Archaiczny pleonazm czy remedium?, [in:] Mączyńska E., Pysz Piotr (red.), Społeczna Gospodarka Rynkowa i integracja europejska w czasach dziejowego przełomu, Polskie Towarzystwo Ekonomiczne \& Fundacja Konrada Adenauera, Przedstawicielstwo w Polsce, Warszawa,

Mączyńska E., Pysz P. (2020), Po co nam społeczna gospodarka rynkowa?, Ekonomista, 2, 206231.

Mises L. (2011), Teoria a historia. Interpretacja procesów społeczno-gospodarczych, Wydawnictwo Naukowe PWN: Instytut Ludwiga von Misesa, Warszawa.

Myszczyszyn J. (2019), Wykorzystanie analizy kliometrycznej w ocenie wpływu kolei żelaznych na wzrost gospodarczy Niemiec, Zachodniopomorski Uniwersytet Technologiczny w Szczecinie, Szczecin.

North D.C. (1981), Structure and Change in Economic History, Norton, New York - London.

North D.C. (1990), Institutions, Institutional Change and Economic Performance, Cambridge University Press, New York.

North D.C. (2014), Zrozumieć przemiany gospodarcze, Wolters Kluwer, Warszawa.

Osińska M. (2019), Matematyk i filozof z zamiłowania, badacz z natury, ekonomista $z$ wyboru, Głos Uczelni, Czasopismo Uniwersytetu Mikołaja Kopernika w Toruniu, 7-10, 31-34.

Piątkowski M. (2018), Europe's Growth Champion, Oxford University Press, New York.

Piketty i co dalej? Plan dla ekonomii i nierówności, (2018), Boushey H., DeLong J.B., Steinbaum M. (eds.), Wydawnictwo Naukowe PWN, Warszawa.

Piketty T. (2015), Kapitał w XXI wieku, Wydawnictwo Krytyki Politycznej, Warszawa.

Piketty T. (2018), W strone pogodzenia ekonomii z naukami społecznymi. Lekcja Kapitatu w XXI wieku, [in:] Boushey H., DeLong J.B., Steinbaum M. (eds.), Piketty i co dalej? Plan dla ekonomii i nierówności, Wydawnictwo Naukowe PWN, Warszawa, 607-632.

Piketty T. (2020), Capital and Ideology, The Belknap Press of Harvard University Press, Cambridge, Massachusetts, London.

Popper K.R. (2002), Logika odkrycia naukowego, Fundacja Aletheia, Warszawa.

Postuła M. (2019), Polityka społeczno-gospodarcza w UE. Finanse na poziomie krajowym, europejskim i globalnym, Wydawnictwo Naukowe PWN, Warszawa.

Reisman G. (2015) Kapitat i kapitalizm XXI wieku, Wydawnictwo Fijorr, Warszawa.

Rodrik D. (2011), Jedna ekonomia, wiele recept. Globalizacja, instytucje, wzrost gospodarczy, Wydawnictwo Krytyki Politycznej, Warszawa. 
Rodrik D. (2019), Rzady ekonomii, Wydawnictwo Naukowe PWN, Warszawa.

Skidelsky R. (2020a), What's Wrong with Economics? A Primer for the Perplexed, Yale University Press, New Haven, London.

Słodowa-Hełpa M (2015a), Conditions of integrated development, [in:] Jańczuk L. (ed.), Integrated regional development. Conceptual, financial and organizational aspects, Lublin.

Słodowa-Hełpa M. (2013a), Inteligentne specjalizacje regionów - wyzwania, możliwości i dylematy, Roczniki Nauk Społecznych, 5(41), 1, 87-121.

Słodowa-Hełpa M. (2013b), Rozwój zintegrowany. Warunki, wymiary, wyzwania, CeDeWu, Warszawa.

Słodowa-Hełpa M. (2014), Dokad zmierzamy - odnowa czy od nowa? Nadzieje, obawy i dylematy zwiazane $z$ instytucjonalnym stymulowaniem zintegrowanego rozwoju w Polsce, Nierówności Społeczne a Wzrost Gospodarczy, 37(1), 20-42.

Słodowa-Hełpa M. (2015b), Interdyscyplinarna natura paradygmatu rozwoju - uwarunkowania i propozycje usprawnienia dialogu, Nierówności Społeczne a Wzrost Gospodarczy, 41(1), 67-92.

Słodowa-Hełpa M. (2015c), Odkrywanie na nowo dobra wspólnego, Nierówności Społeczne a Wzrost Gospodarczy, 43(3), 8-20.

Słodowa-Hełpa M. (2019), Przeszłość w procesie poszukiwania recept na zarządzanie teraźniejszością oraz kreowanie przyszłości, Nierówności Społeczne a Wzrost Gospodarczy, 57(1), 35-49.

Topolski J. (1983), Teoria wiedzy historycznej, Wydawnictwo Poznańskie, Poznań.

Topolski J. (1996), Jak się pisze i rozumie historię. Tajemnice narracji historycznej, Rytm, Warszawa.

Topolski J. (1998), Świat bez historii, Wydawnictwo Poznańskie, Poznań.

Wallerstein I. (2004), Koniec świata jaki znamy, Wydawnictwo Scholar, Warszawa.

Wallerstein I. (2007), Analiza systemów - światów, Wydawnictwo Akademickie Dialog, Warszawa.

Wilkin J. (2019), Nauka przekracza wszelkie granice, także w ekonomii, [in:] Gorynia M. (ed.), Ewolucja nauk ekonomicznych. Jedność a różnorodność, relacje do innych nauk, problemy klasyfikacyjne, PAN, 57-68.

Wojtyna A. (2019), Trwałe czy przejściowe zmiany w badaniach ekonomicznych w reakcji na ostatni kryzys?, [in:] Gorynia M. (ed.), Ewolucja nauk ekonomicznych. Jedność a różnorodność, relacje do innych nauk, problemy klasyfikacyjne, PAN, Warszawa, 69-77.

Woźniak M.G. (2017), Nierówności a wzrost gospodarczy (uwagi na marginesie ksią̇̇ki Grzegorza Malinowskiego Nierówności i wzrost gospodarczy. Sojusznicy czy wrogowie), Ekonomista, 3, 347-358.

Woźniak M.G. (2019a), Czy możliwa i potrzebna jest ekonomia zintegrowanego rozwoju, [in:] Mączyńska E. (ed.), Ekonomia i polityka. Wokót teorii Grzegorza W. Kołodko, Wydawnictwo Naukowe PWN, Warszawa, 31-50.

Woźniak M.G. (2019b), Gospodarka Polski 1918-2018, Tom 1, W kierunku zintegrowanego rozwoju, Wydawnictwo Naukowe PWN, Warszawa.

Woźniak M.G. (2020), Gospodarka Polski 1918-2018, Tom 3, Modernizacja dla zintegrowanego rozwoju, Wydawnictwo Naukowe PWN, Warszawa.

\section{Studies in electronic format}

Ajl M. (2019), Immanuel Wallerstein (1930-2019), https://developingeconomics.org /2019/09/23/immanuel-wallerstein-1930-2019/, accessed 04.06.2020.

Bowles p., Carlin W. (2020), The coming battle for the COVID-19 narrative, https://voxeu. org/article/coming-battle-covid-19-narrative, 10 april, accessed 07.08.2020. 
Bregman R. (2020b), Rutger Bregman: 'The virus is contagious, and so is our behavior', https:/ / www.dw.com/en/rutger-bregman-the-virus-is-contagious-and-so-is-our-behavior/ a-52924554, accessed 13.09.2020.

Gadomski W. (2020), Nierówności na świecie rosną? Zależy, jak liczyć, wyborcza.pl 21.01. 2020. Nierówności na świecie rosną? Zależy, jak liczyć (wyborcza.pl), accessed 10.09.2020.

Gorynia M. (2020b), Co nas czeka po Covid-19, Rzeczpospolita, 29. 05. 2020 https://www. rp.pl/Koronawirus-SARS-CoV-2/304059955-Grzegorz-W-Kolodko-Potem-czyliswiat-po-pandemii.html, accessed 10.09.2020.

Gorynia M. (2020c), Czy Covid-19 zmieni gospodarkę i nasze o niej myślenie, Rzeczpospolita, 23.05.2020, https://rp.pl, accessed 08.09.2020.

GoryniaM.(2020d), Koronawirusniejeden mawymiar,https://www.rp.pl/Opinie/200409383Marian-Gorynia-Koronawirus-niejeden-ma-wymiar.html, accessed 08.09.2020.

Hausner J. (2019c), Prof. Jerzy Hausner: jeśli coś się opłaca, to nie znaczy jeszcze, że warto, https:/ / www.forbes.pl/finanse/o-ekonomii-wartosci-i-ekologii-w-biznesie-rozmowa-forbesa-z-prof-jerzym-hausnerem/mznh86d, accessed 17.08.2020.

Kanclerska A. (2017), Anthony B. Atkinson, „Nierówności. Co da się zrobić?” (recenzja), http:/ / wdolnymslasku.com/2017/07/15/anthony-b-atkinson-nierownosci-co-da-sie-zrobicrecenzja/, accessed 17.08.2020.

Kołodko G.W. (2020b), Potem, czyli świat po pandemii, Rzeczpospolita, 13. 04. 2020 https:/ / www.rp.pl/Koronawirus-SARS-CoV-2/304059955-Grzegorz-W-Kolodko-Potemczyli-swiat-po-pandemii.html, accessed 08.08.2020.

Lewicki G. (2020), Nadchodzi nowe średniowiecze. Era erozji państwa, technologicznego zjednoczenia świata i irracjonalizmu, https:/ / wyborcza.pl/Jutronauci/7,165057,26114600, kuj my-miecze-na-nowe-sredniowiecze.html, accessed 27.09.2020.

Little (2017), Philosophy of History, [in:] Zalta E.N. (ed.), Stanford Encyclopedia of Philosophy (Summer 2017 Edition), CSLI, Stanford University, https:/ / plato.stanford.edu/archives/sum2017/, accessed15.09.2020.

Mączyńska E. (2019), PKB powinien być środkiem, a nie celem, Obserwator Finansowy: ekonomia, debata, Polska, świat, accessed 28.09.2020.

Mączyńska E. (2020c), „Nowa Normalność” czy kryzysogenny nieład?, Prof. Mączyńska: „Nowa Normalność" czy kryzysogenny nieład? - Polish Brief, accessed 10.10 2020.

Murphy R.P. (2014), Murphy: Recenzja ksiażki Piketty'ego „Kapitat w XXI wieku”, https:// mi ses.pl/wp-content/uploads/2014/06/Murphy_Recenzja-ksiazki-Pikketyego.pdf, accessed 10.102020.

Piketty T. (2017), Passing of Anthony B. Atkinson, Passing of Anthony B. Atkinson - Le blog de Thomas Piketty (lemonde.fr), accessed 16.07. 2020.

Piketty T. (2020), Jaki świat po covid-19? https://krytykapolityczna.pl/swiat/thomaspiketty-covid-19-komentarz/, accessed 08.10.2020.

Rodrik D. (2020), Dani Rodrik: Wielkie kryzysy sa okazja do wielkich zmian, https://www. bankier.pl/wiadomosc/Dani-Rodrik-Wielkie-kryzysy-sa-okazja-do-wielkich-zmian7885645.html, accessed 10.09.2020.

Skidelsky R. (2020b) International Law and Political Necessity, https:/ / robertskidelsky.com/, accessed 08.10.2020.

Woś R. (2017), Zmarł Anthony Atkinson. Jeden z najważniejszych wspótczesnych ekonomistów, https://www.polityka.pl/tygodnikpolityka/rynek/1656314,1,zmarl-anthonyatkinson-jeden-z-najwazniejszych -wspolczesnych-ekonomistow.read, accessed 24.09.2020. 
ŻakowskiJ. (2017), Ekonomiści (jak Balcerowicz) sięmylą. Nierówności majątkowe mają znaczenie!, https:// www.polityka.pl/tygodnikpolityka/rynek/1690634,1,ekonomisci-jak-bal cerowicz-się-myla-nierownosci-majatkowe-maja-znaczenie.read, accessed 15.07.2020.

Małgorzata Słodowa-Hełpa, Full Professor of the Poznań University of Economics and Business, Department of Macroeconomics and Development Research; Research interests: Concerning socio-economical changes and structural diversity of regions, Conditioning, scale and scope of regional differentiation, historic background influence on current transformation processes, Conditions of integrated development (Rozwój zintegrowany - warunki, wymiary, wyzwania, CeDeWu, Warszawa 2013; Ludność wiejska Wielkopolski w procesie przemian społeczno-ekonomicznych. Przeobrażenia struktury społeczno-zawodowej w latach 19451970, [Rural Population of Wielkopolska Region in the Process of Socio-Economic Transformations Changes of Socio-Professional Structure] PWN, Warszawa-Poznań 1988 - Individual Award Minister of National Education (for the book). 